\title{
GEOCHEMISTRY AND Nd - ISOTOPIC COMPOSITION OF HIGH SILICA RHYOLITES IN THE NEOARCHAEAN MUSOMA-MARA GREENSTONE BELT, NORTHERN TANZANIA: EVIDENCE FOR THE PRESENCE OF OLDER CONTINENTAL CRUST
}

\author{
S Manya \\ Department of Geology, University of Dar es Salaam, P.O. Box 35052 Dar es Salaam \\ Email: shukrani73@udsm.ac.tz
}

\begin{abstract}
The high silica rhyolites of the Kibasuka Hill, although volumetrically minor, constitute a part of the greenstone sequence in the northern Musoma-Mara Greenstone Belt (MMGB). They are characterized by high silica contents $(63.38-81.65 \mathrm{wt} \%)$, very low CaO ( $\leq 0.05$ wt \%), variable to unusually high $\mathrm{K}_{2} \mathrm{O}(2.24-13.43$ wt \%) most likely attributed to strong sericite alteration, and their major element composition are similar to those of melts derived from partial melting of metapelites. The samples have very low concentration of the transition elements, $\mathrm{Sr}(3.13$ - $48.4 \mathrm{ppm})$ and very large negative Europium anomalies (Eu/Eu* $=0.27-$ 0.48). Their Nd isotopic composition reveals that the T-depleted mantle (DM) model ages of the samples are highly variable and range from $2867 \mathrm{Ma}$ to $4015 \mathrm{Ma}$. These geochemical features are consistent with generation of the high silica rhyolites by partial melting of a heterogeneous source composed of juvenile Archaean rocks of the MMGB and older sedimentary rocks. The later imparts to the rocks very old mean crustal residence ages. Partial melting of this suite took place at low-pressure conditions within the continental crust where plagioclase was a stable phase. Such old $T_{D M}$ model ages of up to $4015 \mathrm{Ma}$ recorded by the high silica rhyolites suggest the presence of very old continental crust in the MMGB which has so far not been identified anywhere else in the Tanzania Craton.
\end{abstract}

\section{INTRODUCTION}

The Musoma-Mara greenstone belt (MMGB) of northeastern Tanzania is a Neoarchaean granite-greenstone terrane forming part of the Tanzania Craton (Barth 1990, Borg and Shackleton 1997). The MMGB is a depository of medium to large scale gold deposits with two operating mines at Buhemba and North Mara. Several gold projects are at advanced stages of exploration in various places in the MMGB. Previous documented and published geological works are limited to geological mapping done in the 1960's by Gray and Macdonald (1964) for the northern MMGB, and Mulgrew (1964) for the southern MMGB. Because of the economic potential of the MMGB, the area has recently attracted many geochemical studies including those of Manya et al.
(2006), Manya et al. (2007a, b), Kazimoto (2007) and Mtoro (2007). These works have largely contributed to our modern understanding of the geological evolution of the MMGB and factors that control gold mineralization through geochemical and geochronological studies.

The focus of the present study is the rhyolitic volcanic rocks which form part of the northern MMGB stratigraphy. These rocks were mapped by Gray and Macdonald (1964) and were considered to belong to the lower unit of felsic volcanic rocks of the Nyanzian Supergroup (Fig. 1). The geochemical and $\mathrm{Nd}$ isotopic composition of the rocks is presented with a view to unravel their petrogenesis. 


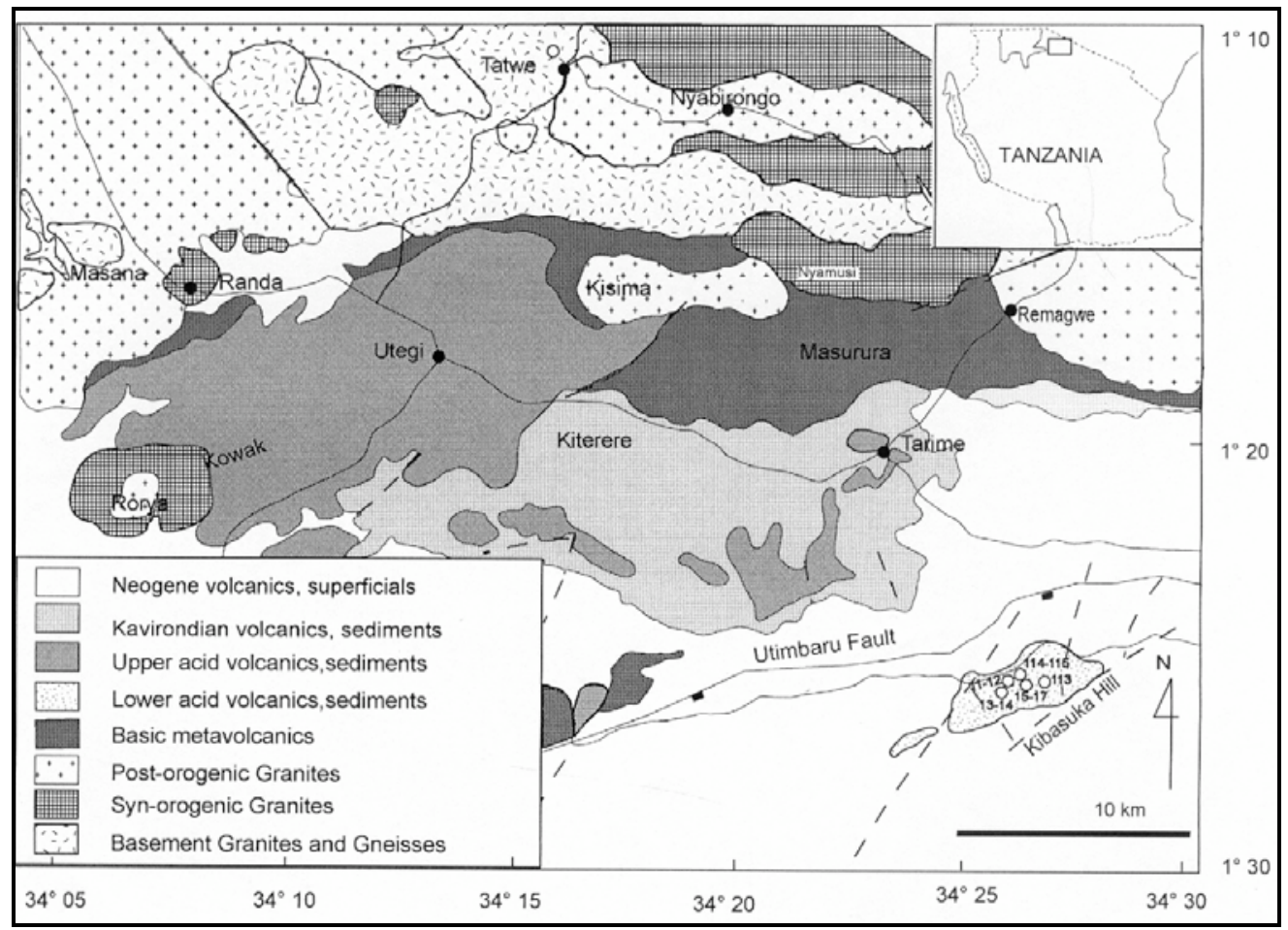

Figure 1: Geological map of northern Musoma-Mara greenstone belt of northern Tanzania (after Gray and Macdonald 1964) showing the sample locations.

\section{Geological background}

The Musoma-Mara Greenstone Belt (MMGB) is located in the northeastern part of the Neoarchaean granite-greenstone terrane of the Tanzania Craton, east of Lake Victoria. The geological setting for the Tanzania Craton and its subdivision into the high-grade Dodoman belt of central Tanzania and the low-grade granite-greenstone terrane of northern Tanzania is described elsewhere (e.g. Borg and Shackleton 1997, Manya et al., 2006). The geology of the northern MMGB has been described by Stockley (1936), Gray and Macdonald (1964) and recently by Manya et al. (2006), Manya et al. (2007a, b). Gray and Macdonald (1964) subdivided the supracrustal rocks of northern MMGB into four units (from bottom upwards): the mafic volcanic rocks, lower felsic volcanic rocks (the object of this study), the upper felsic volcanic rocks of the Nyanzian Supergroup and the metasedimentary rocks of the Kavirondian Supergroup. Manya et al. (2006) reported ion microprobe $\mathrm{U}-\mathrm{Pb}$ zircon ages for the MMGB rocks and showed that the mafic volcanic rocks are high-Mg andesites that are dated at between $2676 \pm 12$ and $2669 \pm 9$ Ma whereas the upper felsic volcanic rocks are dated at $2668 \pm 30 \mathrm{Ma}$ together with the Na-rich granitoids that yielded an age of $2668 \pm 11 \mathrm{Ma}$. The Kavirondian volcanic rocks yielded a zircon $\mathrm{U}-\mathrm{Pb}$ age of $2667 \pm 8$ Ma (Manya et al. 2006). The MMGB magmatism was concluded at $2649 \pm 36 \mathrm{Ma}$ by the intrusion of post-orogenic K-rich granites (Manya et al. 2006).

The study area forms part of the greenstone sequence in northern MMGB and the study is focussed on rhyolitic volcanic rocks that are volumetrically minor, as they are restricted to the Kibasuka Hill, an isolated, fault-bounded hill that is on the 
downthrown side of the major Utimbaru Fault (Fig. 1). These rocks represent a narrow band of recrystallized, sheared and altered felsic volcanic and volcanoclastic rocks (including lapilli tuff) that are interlayered with detrital sedimentary rocks. Because of their fault-bound nature, the stratigraphic relationship with other rock units in the belt is hard to establish.

\section{MATERIALS AND METHODS}

A total of 10 rhyolitic samples were carefully sampled from fresh outcrops (see figure 1 for sample locations) at Kibasuka Hill. The samples were thin-sectioned and petrographically studied. The samples were analyzed for major elements at the Pheasant Memorial Laboratory (PML) for Geochemistry and Cosmochemistry of the Institute for the Study of the Earth's Interior of Okayama University at Misasa, Japan using a Phillips PW2400 X-ray Fluorescence spectrometer on glass beads made from mixing $0.5 \mathrm{~g}$ of powdered sample and $5 \mathrm{~g}$ of lithium tetraborate as flux (Takei, 2002). Analytical reproducibility between replicate analyses were better than $0.5 \%$. Trace elements were measured using a Yokogawa PMS2000 Inductively Coupled Plasma Mass Spectrometer (ICPMS) fitted with a flow injection system using the methods of Makishima and Nakamura (1997) for Rb, Sr, Y, Cs, Ba, REE, Pb, Th and U; Makishima et al. (1999) for Zr, Hf, $\mathrm{Nb}$ and Ta. Analytical reproducibility between replicate analyses was better than $7 \%$ for trace elements.

Five selected samples were also analyzed for $\mathrm{Nd}$ isotopic compositions in a static multicollection mode, as well as $\mathrm{Sm}$ and $\mathrm{Nd}$ concentrations using a Finnigan MAT262 mass spectrometer at the PML, Misasa, Japan. The analytical procedures for chemical separation and mass spectrometry are described in Makishima and Nakamura (1991). Typical analytical reproducibility was $0.006 \%$ for $\mathrm{Nd}$ isotopes. Normalizing factors to correct for isotopic fractionation during analyses are ${ }^{146} \mathrm{Nd} /{ }^{144} \mathrm{Nd}=0.7219$. Replicate analyses of the La Jolla $\mathrm{Nd}$ standard gave ${ }^{143} \mathrm{Nd} /{ }^{144} \mathrm{Nd}=0.511849 \pm 7$ $(2 \sigma, \mathrm{n}=7$, measurements taken over a period from May to August 2003). Typical blank values are 0.25 and $5 \mathrm{pg}$ for $\mathrm{Sm}$ and $\mathrm{Nd}$, respectively and are therefore negligible.

\section{RESULTS}

Petrographic studies of the samples show that they are composed of feldspar and/or quartz phenocrysts set in a fine-grained groundmass of quartz, feldspar and sericite. Acessory phases include sphene and zircon in some specimens. Plagioclase is strongly altered to sericite and in some samples it has lost its tabular habit (Fig. 2).

Major and trace element compositions for the 10 rhyolitic samples are presented in Table 1 . These samples are generally silicarich rocks and based on $\mathrm{SiO}_{2}$ contents, they can be broadly subdivided into two groups: the low silica group, comprising of two samples (TA 15 and TA 113) that have lower $\mathrm{SiO}_{2}$ values of dacitic composition $(63.38-66.05 \mathrm{wt} \%)$ and the high silica group that consists of eight samples with a fairly restricted range in $\mathrm{SiO}_{2}$ contents $(79.35-81.65 \mathrm{wt} \%)$. The low silica samples correspond with unusually high $\mathrm{K}_{2} \mathrm{O}$ values (12.85-13.43 wt \%) most likely attributed to strong sericte alteration; whereas the high silica samples have low to moderate (2.24-7.10 wt \%) $\mathrm{K}_{2} \mathrm{O}$ contents. This suite shows extremely low $\mathrm{CaO}$ contents $(\leq 0.05 \mathrm{wt} \%)$ along with all other major element compositions which are less than 0.90 wt \%. On the Winchester and Floyd (1977) classification scheme which is based on immobile elements (Fig. 3), these samples can be classified as rhyolites and based on their high silica contents, the samples are in this study termed as highsilica rhyolites. 

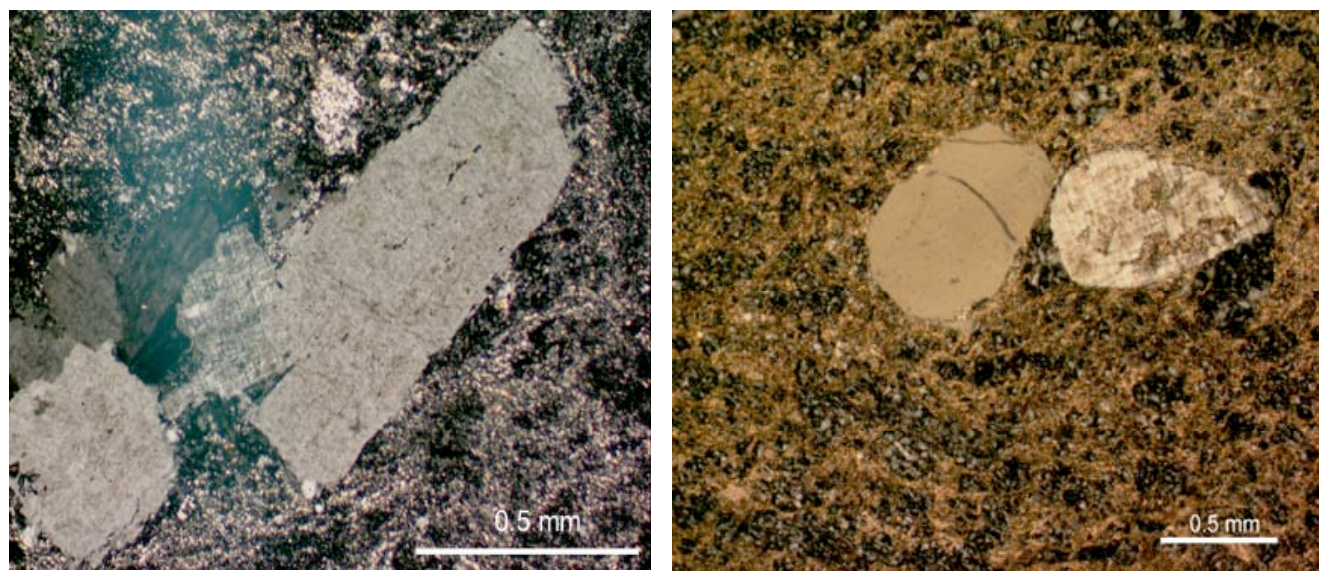

Figure 2: $\quad$ Thin sections of samples TA 113 (left) and TA 15 (right) showing plagioclase and quartz (in TA 15) phenocrysts surrounded by a fine grained matrix mainly composed of sericite.

Table 1: $\quad$ Major (wt \%) and trace (ppm) element compositions for the northern MMGB high silica rhyolites

\begin{tabular}{ccccccccccc}
\hline & & & & & & & & TA & TA & TA \\
\hline $\mathrm{SiO}_{2}$ & 80.0 & 80.3 & 81.3 & 81.6 & 63.4 & 80.3 & 81.0 & 66.1 & 79.4 & 79.4 \\
$\mathrm{TiO}_{2}$ & 0.38 & 0.11 & 0.10 & 0.10 & 0.18 & 0.10 & 0.10 & 0.16 & 0.39 & 0.41 \\
$\mathrm{Al}_{2} \mathrm{O}_{3}$ & 10.6 & 12.4 & 11.2 & 10.3 & 19.9 & 10.8 & 10.5 & 18.0 & 11.0 & 11.5 \\
$\mathrm{Fe}_{2} \mathrm{O}_{3}$ & 0.50 & 0.63 & 0.90 & 0.36 & 0.51 & 0.24 & 0.38 & 0.33 & 0.51 & 0.89 \\
$\mathrm{MnO}$ & 0.00 & 0.00 & 0.00 & 0.00 & 0.00 & 0.00 & 0.00 & 0.00 & 0.00 & 0.00 \\
$\mathrm{MgO}$ & 0.21 & 0.40 & 0.62 & 0.23 & 0.43 & 0.26 & 0.32 & 0.38 & 0.21 & 0.28 \\
$\mathrm{CaO}$ & 0.04 & 0.02 & 0.01 & 0.00 & 0.00 & 0.01 & 0.01 & 0.00 & 0.04 & 0.05 \\
$\mathrm{Na} 2 \mathrm{O}$ & 0.17 & 0.10 & 0.08 & 0.11 & 0.39 & 0.15 & 0.17 & 0.18 & 0.13 & 2.51 \\
$\mathrm{~K}_{2} \mathrm{O}$ & 7.02 & 2.24 & 3.89 & 6.59 & 13.43 & 7.10 & 6.51 & 12.85 & 6.93 & 3.36 \\
$\mathrm{P}_{2} \mathrm{O}_{5}$ & 0.06 & 0.01 & 0.02 & 0.01 & 0.01 & 0.01 & 0.01 & 0.01 & 0.06 & 0.06 \\
$\mathrm{LOI}$ & 0.90 & 3.43 & 1.85 & 0.92 & 1.44 & 1.21 & 1.07 & 1.54 & 1.07 & 1.68 \\
$\mathrm{SUM}$ & 99.8 & 99.6 & 100 & 100.2 & 99.7 & 100.2 & 100.1 & 99.5 & 99.7 & 100.1 \\
$\mathrm{Mg} \#$ & 46 & 55 & 58 & 56 & 63 & 68 & 62 & 69 & 45 & 38 \\
& & & & & & & & & & \\
$\mathrm{Cr}$ & 6.11 & $b 1$ & 4.40 & 4.60 & bl & 5.27 & b1 & 4.82 & bl & bl \\
$\mathrm{Ni}$ & 3.34 & 0.41 & 0.67 & 0.57 & 2.67 & bl & 0.60 & 1.41 & 0.91 & 1.70 \\
$\mathrm{Zr}$ & 354 & 194 & 205 & 177 & 327 & 148 & 176 & 299 & 348 & 394 \\
$\mathrm{Hf}$ & 11.3 & 5.88 & 6.77 & 5.86 & 10.7 & 4.88 & 5.67 & 9.14 & 11.15 & 12.33 \\
$\mathrm{Nb}$ & 22.9 & 9.98 & 10.94 & 9.08 & 15.4 & 6.83 & 9.08 & 13.2 & 23.8 & 26.4 \\
$\mathrm{Ta}$ & 1.79 & 0.94 & 1.03 & 0.79 & 1.38 & 0.68 & 0.73 & 1.17 & 1.86 & 1.97 \\
$\mathrm{Rb}$ & 94.3 & 82.9 & 136 & 125 & 280 & 115 & 117 & 178 & 88.1 & 49.5
\end{tabular}




\begin{tabular}{ccccccccccc}
$\mathrm{Sr}$ & 48.4 & 6.90 & 3.13 & 7.80 & 8.27 & 9.40 & 8.69 & 14.6 & 32.8 & 44.1 \\
$\mathrm{Y}$ & 163 & 30.7 & 31.6 & 21.0 & 41.5 & 19.9 & 22.9 & 33.3 & 111.7 & 139.0 \\
$\mathrm{Cs}$ & 1.15 & 0.81 & 1.42 & 0.97 & 2.11 & 1.42 & 1.53 & 2.24 & 1.23 & 0.98 \\
$\mathrm{Ba}$ & 1168 & 153 & 162 & 547 & 620 & 572 & 566 & 508 & 603 & 578 \\
$\mathrm{La}$ & 63.3 & 36.7 & 54.2 & 46.6 & 46.5 & 23.1 & 24.1 & 25.1 & 72.3 & 108.3 \\
$\mathrm{Ce}$ & 135 & 78.7 & 116 & 91.7 & 98.4 & 51.4 & 55.9 & 52.4 & 151 & 151 \\
$\mathrm{Pr}$ & 16.0 & 8.63 & 12.5 & 9.45 & 9.97 & 4.87 & 5.33 & 5.23 & 18.4 & 21.3 \\
$\mathrm{Nd}$ & 67.3 & 31.2 & 45.8 & 33.4 & 34.3 & 17.5 & 18.7 & 17.9 & 75.6 & 82.6 \\
$\mathrm{Sm}$ & 15.4 & 5.28 & 8.63 & 5.54 & 6.74 & 3.04 & 3.66 & 3.95 & 17.0 & 17.2 \\
$\mathrm{Eu}$ & 2.41 & 0.59 & 0.66 & 0.57 & 1.01 & 0.41 & 0.50 & 0.53 & 2.79 & 2.56 \\
$\mathrm{Gd}$ & 15.9 & 4.34 & 6.55 & 4.28 & 6.54 & 2.81 & 3.57 & 4.25 & 18.2 & 17.2 \\
$\mathrm{~Tb}$ & 2.75 & 0.72 & 0.94 & 0.64 & 1.15 & 0.50 & 0.61 & 0.86 & 3.28 & 2.86 \\
$\mathrm{Dy}$ & 18.7 & 4.55 & 5.37 & 3.65 & 6.77 & 3.17 & 3.92 & 5.56 & 19.7 & 18.0 \\
$\mathrm{Ho}$ & 3.77 & 1.06 & 1.12 & 0.77 & 1.27 & 0.69 & 0.83 & 1.18 & 4.09 & 3.86 \\
$\mathrm{Er}$ & 10.5 & 3.13 & 3.19 & 2.23 & 3.05 & 1.99 & 2.26 & 3.04 & 11.1 & 10.4 \\
$\mathrm{Tm}$ & 1.74 & 0.56 & 0.53 & 0.36 & 0.44 & 0.34 & 0.37 & 0.45 & 1.76 & 1.68 \\
$\mathrm{Yb}$ & 12.1 & 4.20 & 3.76 & 2.59 & 2.78 & 2.35 & 2.60 & 3.05 & 10.5 & 11.6 \\
$\mathrm{Lu}$ & 1.64 & 0.58 & 0.56 & 0.37 & 0.37 & 0.33 & 0.37 & 0.42 & 1.58 & 1.59 \\
$\mathrm{~Pb}$ & 12.8 & 3.51 & 3.11 & 5.01 & 9.71 & 4.46 & 4.64 & 7.72 & 7.49 & 5.04 \\
$\mathrm{Th}$ & 19.2 & 14.8 & 18.6 & 16.2 & 28.8 & 13.4 & 14.4 & 25.4 & 19.1 & 16.8 \\
$\mathrm{U}$ & 3.94 & 3.69 & 3.64 & 2.57 & 5.33 & 2.72 & 3.86 & 4.99 & 5.73 & 4.41 \\
& & & & & & & & & & \\
$\mathrm{La} / \mathrm{Yb}$ & 5.2 & 8.8 & 14.4 & 18.0 & 16.8 & 9.81 & 9.27 & 8.21 & 6.86 & 9.37 \\
$\mathrm{Eu} / \mathrm{Eu} *$ & 0.47 & 0.37 & 0.27 & 0.36 & 0.46 & 0.43 & 0.43 & 0.40 & 0.48 & 0.46 \\
$(\mathrm{La} / \mathrm{Yb})$ & & & & & & & & & & \\
$\mathrm{CN}$ & 3.53 & 5.90 & 9.71 & 12.1 & 11.3 & 6.62 & 6.25 & 5.54 & 4.63 & 6.32 \\
\hline & & & & & & & & & &
\end{tabular}

$\mathrm{bl}=$ below detection limit

The samples have very low concentrations of transition elements, some of which showed to be below detection limit. The concentrations of the Large Ion Lithophile Elements (LILE) are highly variable with $\mathrm{Rb}$ contents of $49.5-280 \mathrm{ppm}$, a feature which is also shared by $\mathrm{Ba}$ concentrations (153 $1168 \mathrm{ppm})$. The samples have unusually low contents of $\mathrm{Sr}(3.13-48.4 \mathrm{ppm})$.

On chondrite-normalized diagrams (Fig. 4), the samples show patterns with slight enrichment of the LREE relative to HREE characterized by low $\mathrm{La} / \mathrm{YbCN}=3.53-12.1$. The samples display strongly negative $\mathrm{Eu}$ anomalies $\left(\mathrm{Eu} / \mathrm{Eu}^{*}=0.27-0.48\right.$, average
0.41). On primitive, mantle-normalized spidergrams (Fig. 5), the samples display coherent patterns with moderate to strong depletion in $\mathrm{Ba}$ and $\mathrm{Sr}$ as well as $\mathrm{Nb}$, Ta and Ti. The samples are also characterized by enrichment in Th, $\mathrm{U}$ and $\mathrm{K}$ but not $\mathrm{Pb}$. Samples TA 15 and TA 113 plot together with the majority of the samples in the spidergram and not as an exclusive group as shown in major element composition.

The samples have ${ }^{147} \mathrm{Sm} /{ }^{144} \mathrm{Nd}$ ratios that range between 0.1020 and 0.1466 and ${ }^{143} \mathrm{Nd} /{ }^{144} \mathrm{Nd}$ ratios of between $0.510910 \pm 8$ and $0.511895 \pm 10$. Their corresponding $\mathrm{T}_{\mathrm{DM}}$ ages are highly variable and range from 2867 Ma to $4015 \mathrm{Ma}$ (Table 2). 


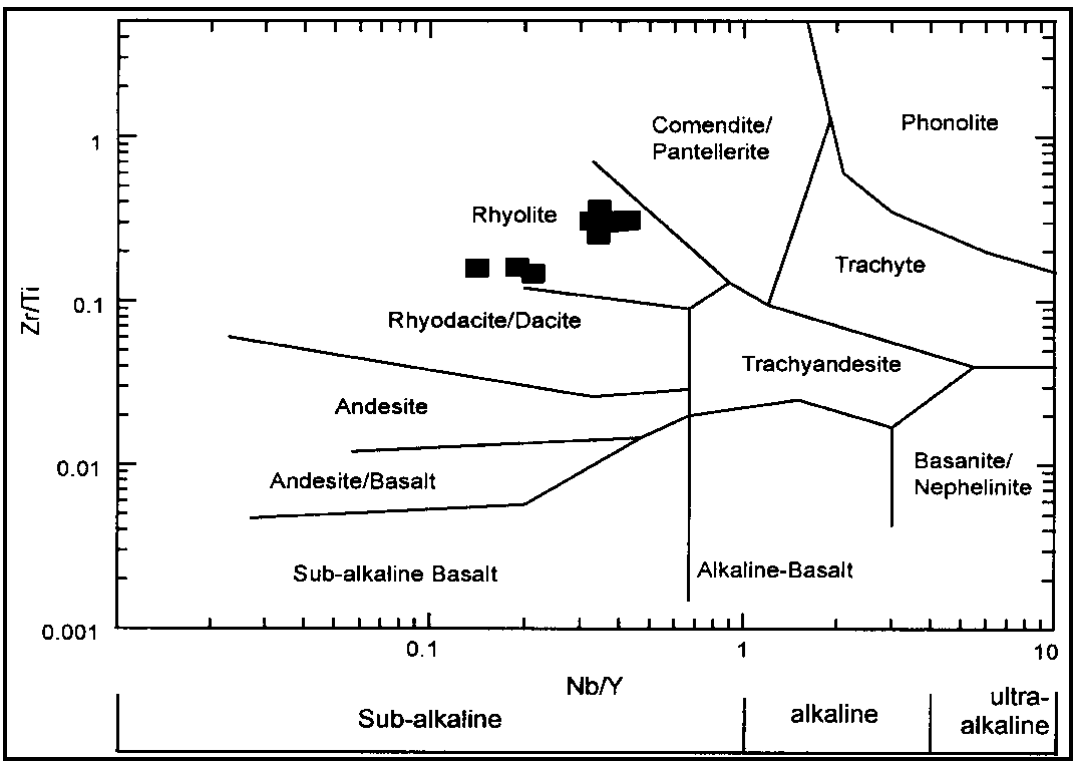

Figure 3: $\quad \mathrm{Zr} / \mathrm{Ti}-\mathrm{Nb} / \mathrm{Y}$ classification diagram of Winchester and Floyd (1977) for the northern MMGB high silica rhyolites.

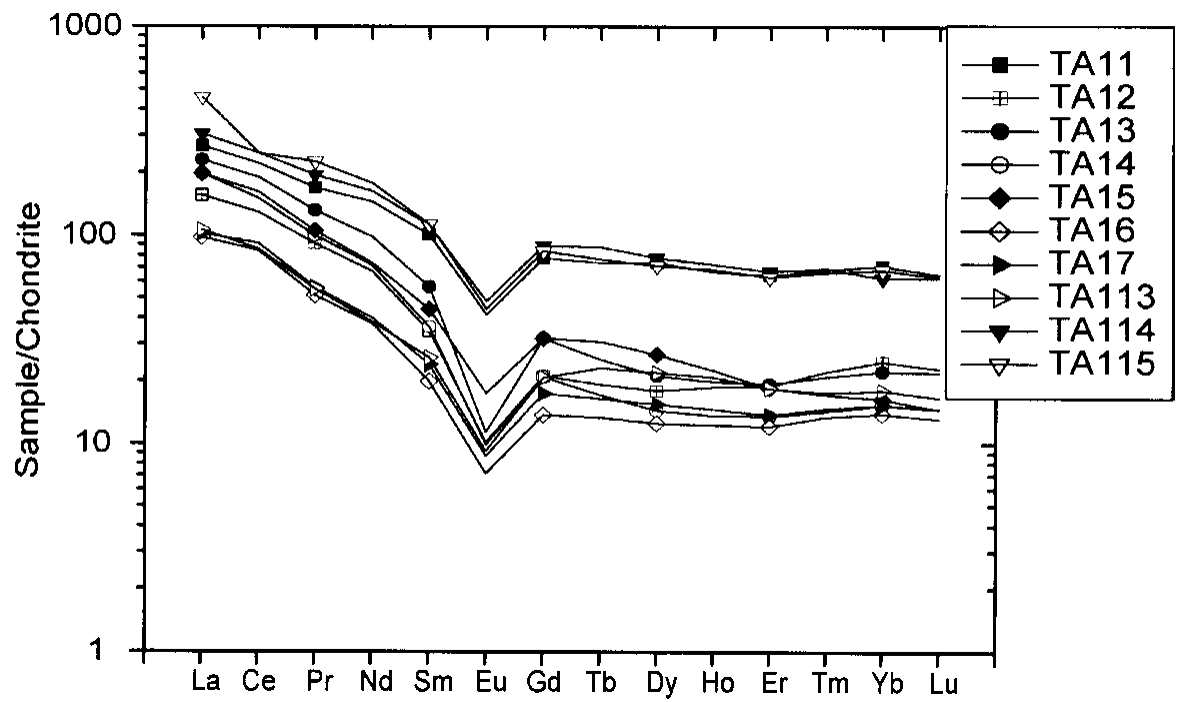

Figure 4: Chondrite-normalized rare earth elements diagram (normalizing values after Sun and McDonough 1989) for the northern MMGB high silica rhyolites. 


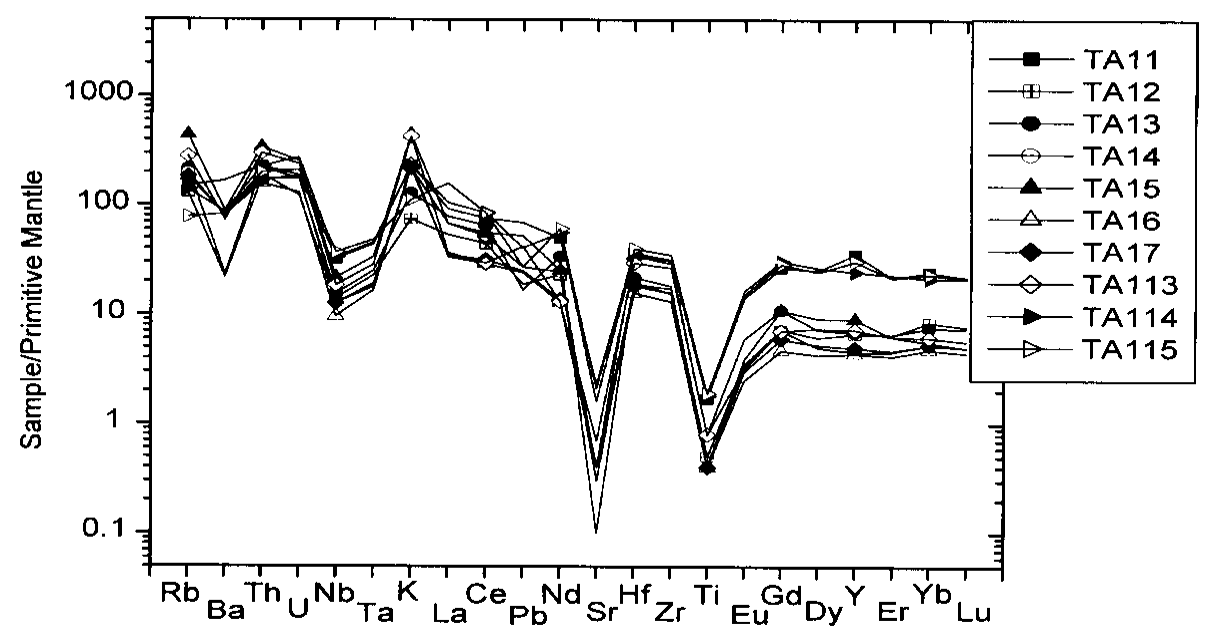

Figure 5: Primitive mantle normalized extended trace elements diagram (normalizing values after Sun and McDonough 1989) for the northern MMGB high silica rhyolites.

Table 2: $\quad$ Sm-Nd isotopic data for the high silica rhyolites from northern MMGB

\begin{tabular}{cccccc}
\hline Sample & Sm ppm & Nd ppm & ${ }^{147} \mathrm{Sm} /{ }^{144} \mathrm{Nd}$ & ${ }^{143} \mathrm{Nd} /{ }^{144} \mathrm{Nd}$ & $\mathrm{T}_{\mathrm{DM}}(\mathrm{Ma})$ \\
\hline TA 11 & 15.22 & 65.90 & 0.1396 & $0.5117039 \pm 9$ & 2975 \\
TA 14 & 5.33 & 31.55 & 0.1020 & $0.510910 \pm 8$ & 3050 \\
TA 15 & 6.63 & 33.62 & 0.1193 & $0.511041 \pm 7$ & 3393 \\
TA 115 & 20.06 & 82.56 & 0.1466 & $0.511895 \pm 10$ & 2867 \\
TA 113 & 4.22 & 19.33 & 0.1321 & $0.510989 \pm 12$ & 4015 \\
\hline
\end{tabular}

Calculations are based on a decay constant of $6.54 \times 10^{-12}$ per year for ${ }^{147} \mathrm{Sm}$ and DM values for $\mathrm{Nd}$ are $\left({ }^{143} \mathrm{Nd} /{ }^{144} \mathrm{Nd}\right)_{\text {today }}=0.51316,\left({ }^{147} \mathrm{Sm} /{ }^{144} \mathrm{Nd}\right)$ today $=0.2137$

\section{DISCUSSION}

The samples have very low concentrations of $\mathrm{Cr}$ and Ni suggestive of derivation from an evolved crustal source. They also possess extremely low contents of $\mathrm{Sr}(3-48 \mathrm{ppm}$, average $18 \mathrm{ppm}$ ) and strongly negative $\mathrm{Eu}$ anomalies $\left(\mathrm{Eu} / \mathrm{Eu}^{*}=0.27-0.48\right.$, average $0.41)$. The low $\mathrm{Sr}$ content is accompanied by low $\mathrm{CaO}$ contents. These elements are considered to be mobile under secondary processes (Rollinson, 1993) and this could be one way to explain their low abundances. Alternatively, their low abundance could reflect a primary feature. HFSE and REE are considered by many researchers (e.g. Jochum et al., 1991) to be immobile during alteration of Archaean volcanic rocks, a fact supported by the coherent REE patterns of the samples (Fig. 4). Thus, the low contents of $\mathrm{Eu}$, which together with $\mathrm{Sr}$ and $\mathrm{CaO}$ strongly partition in plagioclase mineral, suggest that plagioclase was involved in the magma generation/evolution either as a fractionating phase during magmatic differentiation or its retention as a residual phase during partial melting. Since these rocks are not spatially associated with other volcanic rocks in the MMGB, this suggests that the geochemical features reflect partial 
melting of a plagioclase-bearing source rather than magmatic differentiation.

The low $\mathrm{Sr}$ contents of these rocks are associated with very low contents of $\mathrm{CaO}(<$ $0.05 \mathrm{wt} \%$ ) but high contents of $\mathrm{Ba}$ (average $548 \mathrm{ppm})$. The fact that the high silica rhyolites have extremely low $\mathrm{Sr}$ but high $\mathrm{Ba}$ contents suggest that processes other than the presence of residual plagioclase during partial melting/and or plagioclase fractionation are responsible for the low contents of $\mathrm{CaO}$ and $\mathrm{Sr}$, as well as the negative Eu anomalies. These features can be attributed to formation of the high silica rhyolites by partial melting of metapelites, a fact supported by major element compositional similarities between melts derived from partial melting of metapelites (Patiño Douce and Johnston 1991) and the high silica rhyolites (Table 3 ).

Table 3: Comparison of the major element composition between the MMGB high silica rhyolites and the melts derived from the melting of a sillimanite-bearing metapelite

\begin{tabular}{ccc}
\hline Element & $\begin{array}{c}\text { Average MMGB } \\
\text { high silica } \\
\text { rhyolites }\end{array}$ & $\begin{array}{c}\text { HQ36 melts at } \\
10 \mathrm{kbar} \\
950^{\circ} \mathrm{C}^{\mathrm{a}}\end{array}$ \\
\hline $\mathrm{SiO}_{2}$ & 77.3 & 73.7 \\
$\mathrm{TiO}_{2}$ & 0.20 & 0.40 \\
$\mathrm{Al}_{2} \mathrm{O}_{3}$ & 12.6 & 13.5 \\
$\mathrm{Fe}_{2} \mathrm{O}_{3}$ & 0.53 & 1.70 \\
$\mathrm{MnO}$ & 0.001 & 0.10 \\
$\mathrm{MgO}$ & 0.33 & 0.3 \\
$\mathrm{CaO}$ & 0.02 & 0.10 \\
$\mathrm{Na}$ & 0.40 & 1.10 \\
$\mathrm{~K}_{2} \mathrm{O}$ & 6.99 & 6.90 \\
$\mathrm{P}_{2} \mathrm{O}_{5}$ & 0.03 & 0.00 \\
\hline
\end{tabular}

${ }^{a}$ Experimetal results of Patino Douce and Johnston (1991)

The concentrations of the REE in the rhyolites cover a wide range leading to variable $\mathrm{La} / \mathrm{Yb}$ ratios of between 5.24 and 17.98 (average 10.67). In particular, The HREE contents in the high silica rhyolites are high and variable $(\mathrm{Y}=20-163 \mathrm{ppm}$, average $58 \mathrm{ppm}$ ). Such a large variation in REE concentrations cannot be explained by formation from a homogenous source and as previously argued, the variation might be attributed to formation from a heterogeneous source.

In Sm-Nd system of dating, model ages are used to estimate the time at which a sample separated from its mantle source region and hence giving crust formation ages for igneous and meta-igneous rocks (Rollinson 1993). Studies of the initial ${ }^{143} \mathrm{Nd} /{ }^{144} \mathrm{Nd}$ ratios from Precambrian terranes suggest that the continental crust formed from a depleted mantle and hence model ages are calculated with reference to the depleted mantle (DM) reservoir. Although the use of model ages is faced with several limitations (Rollinson 1993), they offer an insight into the crust formation ages especially with rocks whose REE were not disturbed as those of the Kibasuka Hill rhyolites. The calculated Tdepleted mantle (DM) model ages for the high-slica rhyolites range from $2867 \mathrm{Ma}$ to $4015 \mathrm{Ma}$. The $\mathrm{T}_{\mathrm{DM}}$ ages of $2867 \mathrm{Ma}$ are shared by other volcanic rocks of the MMGB including the high-Mg andesites, dacites and the Na-rich granitoids discussed in Manya et al. (2007a). The variable $T_{D M}$ model ages demonstrate that the high silica rhyolites are derived from a mixture of 
young and very old crust. The old $\mathrm{T}_{\mathrm{DM}}$ model ages of up to $4015 \mathrm{Ma}$ recorded by the high silica rhyolites suggest the presence of very old continental crust in the MMGB which has so far not been identified anywhere else in the Tanzania Craton. This signifies that the rhyolites could be derived from a heterogenous source involving the juvenile material represented by the late Archaean igneous rocks of the MMGB which are represented by samples with younger $\mathrm{T}_{\mathrm{DM}}$ model ages and the very old metapelites represented by samples with very very old $\mathrm{T}_{\mathrm{DM}}$ model ages.

\section{ACKNOWLEDGEMENT}

I am grateful to Sida/SAREC for financial support through the project "Geology and gold mineralization of the Lake Victoria Greenstone Belts" of the Faculty of Science, University of Dar es Salaam. Centre of Excellency (COE) $21^{\text {st }}$ century grants to Eizo Nakamura supported the analytical part of this work.

\section{REFERENCES}

Barth H 1990 Provisional Geological Map of Lake Victoria Gold Fields, Tanzania 1:500000 (with explanatory notes). Geol. Jb. B 72, 59 pp.

Borg G and Shackleton RM 1997 The Tanzania and NE Zaire cratons. In: de Wit MJ and Ashwal LD (eds.). Greenstone Belts. Clarendon Press, Oxford, pp. 608-619.

Gray IM and Macdonald AS 1964 Tanzania Quarter Degree Sheets 4NE and 5NW, Dodoma.

Jochum KP, Arndt NT and Hofmann AW $1991 \mathrm{Nb}-\mathrm{Th}-\mathrm{La}$ in komatiites and basalts: Constraints on komatiite petrogenesis and mantle evolution. Earth. Planet. Sci. Lett. 107: $272-$ 289.

Kazimoto E 2008 Study of integrated geochemical techniques in the exploration for gold in North Mara mines, Tanzania. MSc Thesis, University of Dar es Salaam, 188 pp.
Makishima A and Nakamura 1991 Precise measurement of cerium isotope composition in rock samples. Chem. Geol. 94: 1-11.

Makishima A and Nakamura E 1997 Supression of matrix effects in ICP-MS by high power operation of ICP: Application to precise determination of $\mathrm{Rb}, \mathrm{Sr}, \mathrm{Y}, \mathrm{Cs}, \mathrm{Ba}, \mathrm{REE}, \mathrm{Pb}$, Th and $\mathrm{U}$ at $\mathrm{ng} \mathrm{g}^{-1}$ levels in milligram silicate samples. Geost. Newsletter 21: 307319.

Makishima A, Nakamura E and Nakano T 1999 Determination of zirconium, niobium, hafnium, and tantalum at $\mathrm{ng} \mathrm{g}^{-}$ ${ }^{1}$ levels in geological materials by direct nebulisation of sample HF solution into FI-ICP-MS. Geost. Newsletter 23: 7-20.

Manya S, Kobayashi K, Maboko MAH and Nakamura E 2006 Ion microprobe U-Pb zircon dating of the late Archaean metavolcanic rocks and associated granites of the Musoma-Mara greenstone belt, northeast Tanzania: implications for the geological evolution of the Tanzania Craton. J. Afr. Earth Sci. 45: 355 366.

Manya S, Maboko MAH and Nakamura E 2007a The geochemistry of high-Mg andesite and associated adakitic magmatism in the Musoma-Mara Greenstone Belt, northern Tanzania: possible evidence for Neoarchaean ridge subduction? Precam. Res. 159: 241 259.

Manya S, Maboko MAH and Nakamura E 2007b Geochemistry and Nd-isotpic

composition of potassic magmatism in the Neoarchaean Musoma-Mara Greenstone Belt, northern Tanzania. Precam. Res. 159: $231-240$.

Mtoro M 2007 Geochemical investigation of metavolcanic rocks of the Musoma-Mara greenstone belt in the Suguti area, Northeast Tanzania. M.Sc. Thesis, University of Dar es Salaam, 105 pp.

Mulgrew J 1964 Tanzania Quarter Degree Sheet 12. Geol. Surv. Tanz. Dodoma.

Patiño Douce AE and Johnston AD 1991 Phase equilibria and melt productivity in 
the pelitic system: implications for the origin of peraluminous granitoids and aluminous granulites. Contrib. Mineral. Petrol. 107: 202-218.

Rollinson, H., 1993. Using geochemical data: evaluation, presentation, interpretation. Longman Group UK Limited, London, $352 \mathrm{pp}$.

Stockley GM 1936 Geology of the south and south-eastern regions of the Musoma district. Geol. Surv. Tang. Short Paper 13: 1-48, Dar es Salaam.

Sun SS amd McDonough WF 1989 Chemical and isotopic systematics of oceanic basalts: implication for mantle composition and processes. In: Saunders
$\mathrm{AD}$ and Norry MJ (eds). Magmatism in Ocean Basins. Geol. Soc. Lond. Spec. Publ. 42: 313 - 345.

Takei H 2002 Development of precise analytical techniques for major and trace element concentratons in rock samples and their applications to the Hishikari Gold Mine, southern Kyushu, Japan. Ph.D. Thesis. Graduate school of Natural Science and Technology, Okayama University, pp. 164.

Winchester JA and Floyd PA 1977 Geochemical discrimnation of different magma series and their differentiation products using immobile elements. Chem. Geol. 20: 325-343. 